Nig. J. Biotech. Vol. 33 (2017) 58-65

ISSN: 01891731

Available online at

http://www.ajol.info/index.php/njb/index

and www.biotechsocietynigeria.org

DOI: https://dx.doi.org/10.4314/v33i1.8

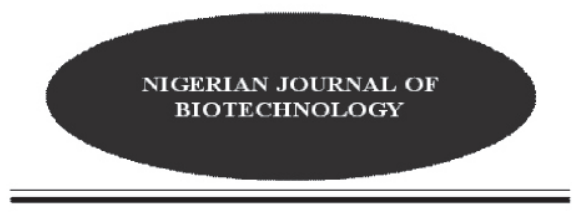

\title{
Detection and molecular characterization of butyrate-producing genes in probiotic lactic acid bacteria for use in livestock
}

\author{
Oloyede, A. R. ${ }^{1}{ }^{2}$, Albert, O. M. ${ }^{3}$ and Arowosegbe, O. A. ${ }^{2}$
}

${ }^{1}$ Biotechnology Centre, Federal University of Agriculture, P.M.B. 2240,110001, Abeokuta, Ogun State, Nigeria; ' Department of Microbiology, Federal University of Agriculture, P.M.B. 2240,110001, Abeokuta, Ogun State, Nigeria; ${ }^{3}$ Department of Science Laboratory Technology, Moshood Abiola Polytechnic, Abeokuta, Ogun State, Nigeria

(Received: 19:05:2017; Accepted:29 :07:2017)

Copyright resides with the authors in terms of the Creative Commons License 4.0. See http://creativecommons.org/licenses/by/4.0/

Condition of use: The user may copy, distribute, transmit and adapt the work, but must recognize the authors and the Nigerian Journal of Biotechnology

\begin{abstract}
Butyrate-producing gut microflora synthesizes and secretes butyrate which serves as source of energy and stimulates rumen development in young animals. The present study was undertaken probiotic potentials. The potential probiotic LAB were characterized by 16S rRNA gene sequencing method. Polymerase chain reaction was then used to detect the butyrate kinase (buk) gene in probiotic LAB strains. The $16 S$ rRNA gene sequencing identified the potential probiotic LAB probiotic potentials were demonstrated by their ability to tolerate low pH, bile acid and lysozyme. The PCR analysis revealed that gene encoding butyrate kinase is present in only Lactobacillus plantarum PLB5. The study revealed that these LAB strains could be developed into useful only L. plantarum PLB5 possesses the ability to produce butyrate.

Keywords: Butyrate, probiotic, lactic acid bacteria, 16S rRNA, Polymerase chain reaction

Correspondence: oloyedear@funaab.edu.ng; +2348030801514
\end{abstract} to characterize and screen butyrate-producing lactic acid bacteria (LAB) for probiotic use in animals in order to manipulate their gut flora for the benefit of host health and productivity. Twenty strains of LAB isolates from faeces of West African Dwarf (WAD) goats were screened for as strains of Lactobacillus acidophilus, L. reuteri, L. plantarum, L. helveticus and L. fermentum. Their probiotics in improving the health, nutrient digestibility and growth performance of livestock, but

\section{Introduction}

Lactic acid bacteria (LAB) play essential roles in the manufacture of many fermented products such as cheese and yoghurt (Perea-Velex et al., 2007). Applications of these organisms are now being extended to the area of growth and health improvement in animals, human and aquaculture, which is known as a probiotic activity (Soccol et al., 2010). Probiotics refer to viable microorganisms that promote or support a beneficial balance of the autochthonous microbial population of the gastrointestinal tract (Holzapfel et al., 2001). Such microorganisms may not necessarily be constant inhabitants of the gastrointestinal tract, but they should have a beneficial effect on the general and health status of man and animal. Several strains of Lactobacillus,
Lactococcus, Streptococcus, Pediococcus, Bifidobacterium, Bacillus and some yeasts (Saccharomyces boulardii and Saccharomyces cerevisiae) are known to possess probiotic properties (Mercenier et al., 2003; Oloyede and Afolabi, 2013). Majority of these probiotic organisms are known as 'generally regarded as safe' (GRAS).

The West African Dwarf (WAD) goats are widely distributed across the rainforest belt of southern Nigeria where they make significant contributions to the livelihoods of impoverished families (Oseni et al., 2006). The WAD goats are not milk animals, they are raised solely for their much valued meat or the chevon considered being of superior quality compared to that of other standard goats. These goats contribute substantially to meat production and hence to the 
economy of West Africa (Adebayo and Chineke, 2011).

Prevention or control of enteric diseases in animals has been reported to be achieved by the incorporation of antibiotics in the feed of the animals. However, the demand for withdrawal of antibiotics from the feed of farm animals has increased the interest of using alternative natural products that allow maintenance of high productivity and reduction of morbidity and mortality in intensive farms. Probiotics as feed additives might benefit the host animal by promoting its growth by competing with harmful gut flora, and stimulating the immune system thereby increasing resistance to infectious agents (Cross, 2002; O'hara et al., 2006).

Short-chain fatty acids such as butyrate, propionate and acetate are the end-products of the dietary carbohydrate breakdown by anaerobic bacteria in the gastrointestinal tract (GIT) of animals and humans (Raz et al., 2007). These fatty acids, most especially butyrate, are the preferred sources of energy (Hold et al., 2003). Butyrate supplies energy and stimulates rumen development in young animals (Defrain et al., 2004). Butyratesynthesizing process involves a pathway that consists of a reaction involving the butyryl-CoA to butyrate using phosphotransbutyrylase and butyrate kinase enzymes (Louis et al., 2004; Abbas, 2009).

Less consideration has been given to the possible use of butyrate-producing bacteria as probiotics for animals. This study was therefore undertaken to characterize probiotic lactic acid bacteria by $16 \mathrm{~S}$ rRNA gene sequencing method as well as to screen for the butyrate-producing lactic acid bacteria for probiotic use in animals, using polymerase chain reaction (PCR) method to amplify bacterial gene encoding butyrate kinase.

\section{Materials and Methods}

Bacterial strains and growth conditions

Twenty lactic acid bacteria (LAB) were isolated from faeces of West African dwarf (WAD) goats using De Mann Rogosa Sharpe (MRS) agar (Oxoid, U.K), incubated at $35^{\circ} \mathrm{C}$ under anaerobic conditions. These isolates were screened for probiotic activity by subjecting them to series of invitro probiotic tests such as tolerance to low $\mathrm{pH}$, tolerance to bile, tolerance to lysozyme, antibiotics resistance patterns, antibacterial activity against pathogenic bacteria of WAD goats and haemolytic test using the methods described by Oloyede and Afolabi (2013) with little modifications. Gram staining, catalase test, endospore test, oxidase test, citrate test, methyl red test, indole test, voges proskauer test and sugars fermentation tests were then carried out on the probiotic bacterial isolates.

Molecular characterization of probiotic lactic acid bacteria by $16 \mathrm{~S}$ rRNA gene sequencing

The genomic DNA of the probiotic lactic acid bacterial strains was extracted using Cetyl Trimethyl Ammonium bromide (CTAB) method as described by Chen et al. (2006) and Sridhar et al. (2010) with little modifications.

An overnight broth culture $(2.0 \mathrm{ml})$ was centrifuged at $14,000 \mathrm{rpm}$ at $25^{\circ} \mathrm{C}$ for 1 minute to pellet the cells. The supernatant was carefully discarded and the pellets were re-suspended in $400 \mu$ l of pre-warmed CTAB buffer and vortexed gently. $75 \mu \mathrm{l}$ of $10 \%$ SDS was added to the suspension. Thereafter, $12 \mu \mathrm{l}$ of lysozyme solution $(400 \mathrm{mg} / \mathrm{ml})$ was added to each cell suspension and mixed gently. The suspension was heated in a water bath at $65^{\circ} \mathrm{C}$ for 30 minutes. It was then allowed to cool. $10 \mu \mathrm{l}$ of $20 \mathrm{mg} / \mathrm{ml}$ of proteinase $\mathrm{K}$ solution was added to the suspension and incubated at $37^{\circ} \mathrm{C}$ for 30 minutes. After incubation, 500 $\mu$ of chloroform was added and mixed thoroughly. The cell suspension was then centrifuged at $10,000 \mathrm{rpm}$ for 10 minutes and the supernatant was carefully collected into a fresh micro centrifuge tube. $10 \mu \mathrm{l}$ of RNAse solution was added to the supernatant and incubated at $37^{\circ} \mathrm{C}$ for 30 minutes. After this, 500 $\mu$ l of isopropanol was added to the mixture and kept at $-20^{\circ} \mathrm{C}$ for 1 hour. After one hour, the suspension was centrifuged at $10,000 \mathrm{rpm}$ for 10 minutes and the supernatant was carefully discarded. The pellet was rinsed with $500 \mu \mathrm{l}$ of $70 \%$ ethanol, mixed thoroughly and then centrifuged at $10,000 \mathrm{rpm}$ for 10 minutes, so as to remove residual contaminants. The supernatant was discarded and the DNA pellet was airdried for $1 \mathrm{hr}$. Finally, the DNA pellet was re-suspended in $200 \mu \mathrm{L}$ of nuclease-free water.

The concentration and purity of DNA extracted from each isolate was determined using NanoDrop Lite Spectrophotometer.

The 16S rRNA genes of the probiotic LAB strains were amplified by polymerase chain reaction using a pair of $16 \mathrm{~S}$ rRNA universal primers designated as $27 \mathrm{~F}$ (5'- AGA GTT TGA TCC TGG CTC AG-3') for forward and 1492R (ACG GCT ACC TTG TTA CGA CTT-3') for reverse (Jiang et al., 2006; Abdul Hamid et al., 2012).

Polymerase chain reaction was performed in a $20 \mu \mathrm{l}$ reaction volume containing $2.0 \mu \mathrm{l}$ of template DNA $(1 \mu \mathrm{g}), 10.0 \mu \mathrm{l}$ of $2 \times$ PCR master mix (Norgen Biotek Corporation, Canada) which contains Taq DNA polymerase, dNTPs, reaction buffer, $\mathrm{MgCl}_{2}, \mathrm{KCl}$ and PCR enhancer/stabilizer; $1.0 \mu \mathrm{l}$ of forward primer $(2.5 \mu \mathrm{M})$, $1.0 \mu \mathrm{l}$ of reverse primer $(2.5 \mu \mathrm{M})$ and $6.0 \mu \mathrm{l}$ of nucleasefree water. PCR reactions were carried out in a TC-412 Thermocycler employing the following amplification conditions. Initial denaturation step of $94^{\circ} \mathrm{C}$ for 2 
minutes, followed by 35 amplification cycles each consisting of denaturation at $94^{\circ} \mathrm{C}$ for 30 seconds, annealing at $50.2^{\circ} \mathrm{C}$ for 30 seconds and extension or elongation at $72^{\circ} \mathrm{C}$ for 2 minutes. Reactions were terminated at final extension of $72^{\circ} \mathrm{C}$ for 10 minutes. The amplified polymerase chain reaction (PCR) products were analysed in a $1.0 \%(\mathrm{w} / \mathrm{v})$ agarose gel electrophoresis in $1 \times$ TAE buffer at $100 \mathrm{~V}$ for 1 hour. A $1 \mathrm{~kb}$ DNA ladder (O'GeneRuler) was used as molecular size marker. The gel was then stained with ethidium bromide solution, visualised in a gel documentation system and photographed. The amplicons were purified and sequenced. Sequence assembly and alignment were carried out using CLC bio software. Gene sequences were compared with GenBank database at National Centre for Biotechnology Information (NCBI) using BLASTn search tool to identify the strains. The phylogenetic tree was constructed by the neighbour-joining method using CLC bio software. The topologies of trees were evaluated by bootstrap analysis of the sequence data with the software based on 100 random resamplings.

Amplifications of gene encoding butyrate kinase (buk gene) by Polymerase chain reaction

The presence of gene encoding the synthesis of butyrate i.e. butyrate kinase gene (buk gene) in probiotic lactic acid bacterial strains was determined by polymerase chain reaction (PCR). The nucleotide sequence of the forward primer used in PCR of butyrate kinase gene was 5'- TGC GTC AAA TCT TGG TGG AA-3' and that of the reverse primer was 5'- AAG TAC CTC CAC CCA GGT GT-3' (Raz et al., 2007).

Each of the polymerase chain reactions was performed in a $10 \mu$ l reaction volume containing $1.5 \mu \mathrm{l}$ of template DNA $(1 \mu \mathrm{g}), 5.0 \mu \mathrm{l}$ of $2 \times$ PCR master mix (Norgen Biotek Corporation, Canada) which contains Taq DNA polymerase, dNTPs, reaction buffer, $\mathrm{MgCl}_{2}, \mathrm{KCl}$ and $\mathrm{PCR}$ enhancer/stabilizer; $1.0 \mu \mathrm{l}$ of forward primer $(2.5 \mu \mathrm{M}), 1.0 \mu \mathrm{l}$ of reverse primer $(2.5 \mu \mathrm{M})$ and $1.5 \mu \mathrm{l}$ of nuclease-free water. PCR reactions were carried out in a TC-412 Thermocycler. The amplification conditions consisted of an initial denaturation step of $94^{\circ} \mathrm{C}$ for 5 minutes, followed by 36 amplification cycles each consisting of denaturation at $94^{\circ} \mathrm{C}$ for 30 seconds, annealing at $51.4^{\circ} \mathrm{C}$ for 30 seconds and extension or elongation at $72^{\circ} \mathrm{C}$ for 2 minutes. Reactions were terminated at final extension of $72^{\circ} \mathrm{C}$ for 5 minutes. The PCR products were visualized by electrophoresis on a $1 \%(\mathrm{w} / \mathrm{v})$ agarose gels, stained with ethidium bromide in the presence of $100 \mathrm{bp}$ PCR sizer ladder (Norgen Biotek Corporation, Canada). Electrophoresis was performed at $100 \mathrm{~V}$ for 1 hour.

\section{Results}

Characterization of probiotic Lactic acid bacterial strains

Eight out of the twenty lactic acid bacteria (LAB) strains isolated from faeces of WAD goats were observed to possess probiotic characteristics. Microscopically, the probiotic isolates were Gram positive rods, non-motile, catalase negative and lack endospore. The PCR products obtained following amplification with the 16S rRNA primers were estimated to be $1,500 \mathrm{bp}$ in size (Plate 1 ). The results of the phenotypic characteristics and sequence similarity (\%) by BLASTN in GenBank of the National Center for Biotechnology Information (NCBI) library are shown in Tables 1 and 2. Genotypic identification results showed that the probiotic lactic acid bacteria isolated from faeces of WAD goats belonged to the species of Lactobacillus. The strains showed $95-100 \% 16 \mathrm{~S}$ rRNA sequence homology to Lactobacillus fermentum (2 isolates), Lactobacillus acidophilus (2 isolates), Lactobacillus reuteri (1 isolate), Lactobacillus plantarum (2 isolates) and Lactobacillus helveticus (1 isolate) (Table 2). These isolates were able to grow at $\mathrm{pH}$ 1.5, 2.0 and 2.5 for about 4 hours incubation (Data not shown). The isolates also fulfilled other in-vitro probiotic criteria such as tolerance to bile acids and lysozyme.

The phylogenetic tree of the isolated probiotic lactic acid bacteria, based on 16S rRNA sequences (Neighbor-Joining analysis of CLC bio software) grouped them in three clusters (Figure 1). 
Table 1: Phenotypic characteristics of Probiotic Lactic acid bacteria isolated from faeces of WAD goats

\begin{tabular}{|c|c|c|c|c|c|}
\hline \multirow[t]{2}{*}{ Properties } & \multicolumn{5}{|c|}{ Suspected lactic acid bacteria } \\
\hline & $\begin{array}{l}\text { Lactobacillus } \\
\text { acidophilus }\end{array}$ & $\begin{array}{c}\text { Lactobacillus } \\
\text { reuteri }\end{array}$ & $\begin{array}{l}\text { Lactobacillus } \\
\text { fermentum }\end{array}$ & $\begin{array}{l}\text { Lactobaaillus } \\
\text { plantarum }\end{array}$ & $\begin{array}{c}\text { Lactobadilus } \\
\text { helveticus }\end{array}$ \\
\hline Gram reaction & +ve & +ve & +ve & +ve & +ve \\
\hline Morphology & Rods & Rods & Rods & Rods & Rods \\
\hline Catalase & ve & -ve & -ve & -ve & -ve \\
\hline Motility & ve & -ve & -ve & -ve & ve \\
\hline Endospore & -ve & -ve & -ve & -ve & ve \\
\hline Indole & -ve & -ve & +ve & -ve & -ve \\
\hline Oxidase & -ve & -ve & -ve & -ve & -ve \\
\hline Citrate & $+\mathrm{ve}$ & -ve & -ve & -ve & -ve \\
\hline Methyl red & ve & -ve & -ve & -ve & -ve \\
\hline Voges proskauer & +ve & +ve & +ve & +ve & +ve \\
\hline D-glucose & +ve & +ve & tve & +ve & +ve \\
\hline D-mannitol & + ve & +ve & +ve & +ve & +ve \\
\hline D-lactose & $+v e$ & +ve & +ve & -ve & +ve \\
\hline L-xylose & -ve & +ve & tve & -ve & ve \\
\hline D-sorbitol & ve & +ve & -ve & +ve & -ve \\
\hline D-maltose & +ve & +ve & +ve & +ve & +ve \\
\hline D-fructose & +ve & +ve & +ve & +ve & +ve \\
\hline L-rhamnose & ve & +ve & -ve & +ve & tve \\
\hline
\end{tabular}

Note:

-ve: negative reaction +ve: positive reaction

Plate 1: $16 \mathrm{~S}$ rRNA gene PCR amplicons of Genomic DNA of probiotic lactic acid bacteria isolated from faeces of WAD goats M: 1Kb DNA ladder (O'GeneRuler), 1: PLB1, 2: PLB2, 3: PLB3, 4: PLB4, 5: PLB5, 6: PLB6, 7: PLB7 and 8: PLB8

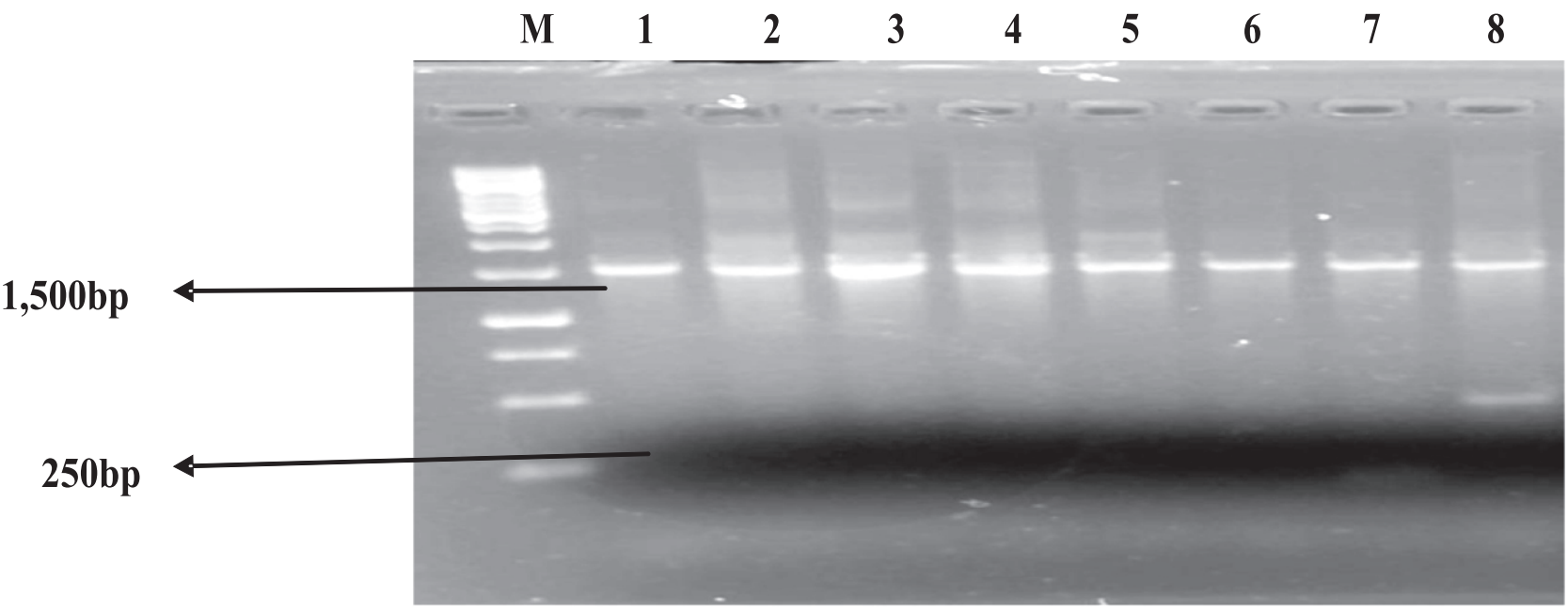


Table 2: Molecular identification of probiotic lactic acid bacteria isolated from faeces of WAD goats based on 16S rRNA gene sequencing method

\begin{tabular}{clc}
\hline LAB isolate & \multicolumn{1}{c}{ Molealar identification } & $\%$ Similanity \\
\hline PLB1 & Lactobacillus acidophilus & 98.0 \\
PLB2 & Lactobacillus reuter & 100.0 \\
PLB3 & Lactobacillus fermentum & 100.0 \\
PLB4 & Lactobacillus acidophilus & 100.0 \\
PLB5 & Lactobacillus plantarum & 100.0 \\
PLB6 & Lactobacillus plantarum & 96.0 \\
PLB7 & Lactobacillus helveticus & 100.0 \\
PLB8 & Lactobacillus fermentum & 98.0 \\
\hline
\end{tabular}

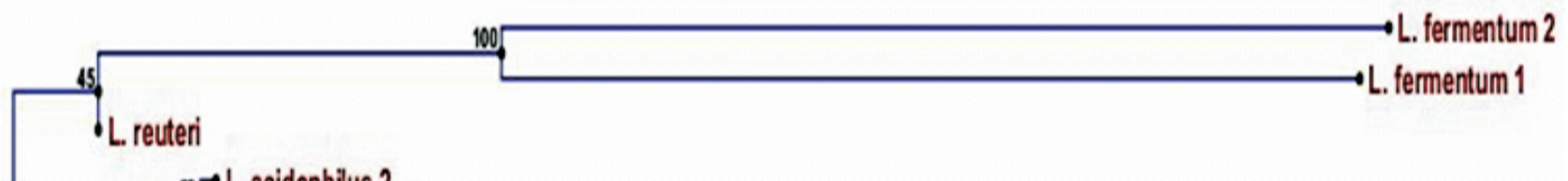

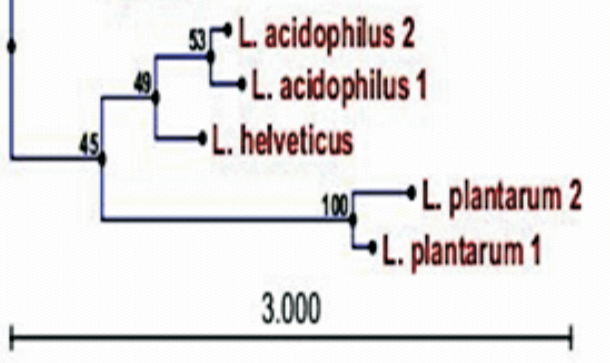

Specific primers were used to amplify gene encoding the production of butyrate i.e. butyrate kinase gene (buk gene) in probiotic lactic acid bacterial strains. A fragment of $280 \mathrm{bp}$ was amplified in only Lactobacillus plantarum PLB5. The gel image showing amplified product of buk gene is shown in Plate 2

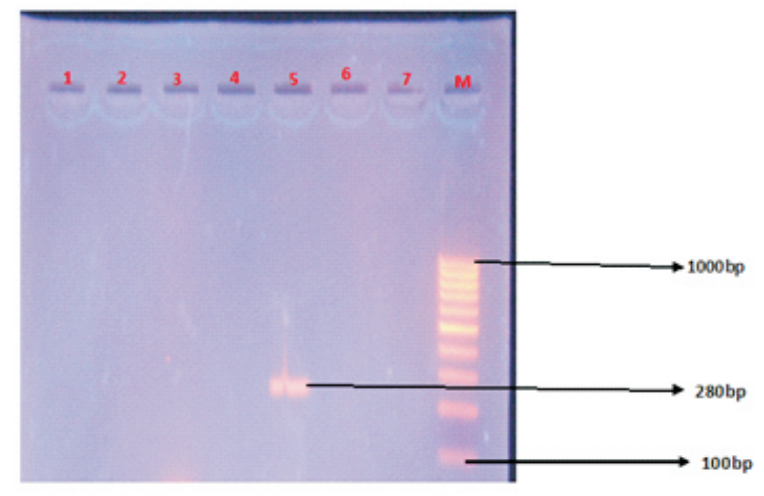

Figure 1: Neighbor-Joining phylogenetic tree of the $16 \mathrm{~S}$ rDNA sequences of the probiotic lactic acid bacteria isolated from faeces of WAD goats

Plate 2: Gel electrophoresis of amplified products of butyrate kinase gene in probiotic lactic acid bacterial strains isolated from faeces of WAD goats $M: 100 \mathrm{bp} P C R$ sizer ladder, 1: PLB1, 2: PLB2, 3: PLB3, 4: PLB4, 5: PLB5, 6: PLB6, 7: PLB7

\section{Discussion}

In recent years, worldwide interest in the use of probiotic bacteria for health promotion and disease prevention has increased significantly in scientific community, consumers and food producers (Bujnakova et al., 2013). This interest is based on the knowledge that the microorganisms to be used as probiotics will possess suitable properties that may have beneficial effects on animal and human health. These properties include bile tolerance, gastric juice resistance as well as the production of antimicrobial compounds such as lactic acid that inhibits the growth of other microorganisms (Hoque et al., 2010). These 
characteristics allow the probiotic organisms to be established in the intestinal tract as well as enable them to survive, grow and perform their beneficial action in the gastrointestinal tract (GIT) of the hosts (Oloyede and Afolabi, 2013). Therefore, probiotic cultures must survive in the environment with gastric and bile acids. Results from this study revealed that 8 out of the $20(40 \%)$ lactic acid bacteria (Lactobacillus acidophilus PLB1, L. acidophilus PLB4, Lactobacillus reuteri PLB2, Lactobacillus plantarum PLB5, Lactobacillus plantarum PLB6, Lactobacillus fermentum PLB3, Lactobacillus fermentum PLB8 and Lactobacillus helveticus PLB7) isolated from faeces of West African Dwarf (WAD) goats could tolerate acidic medium and gastric bile, thus, these $L A B$ strains would be able to survive high acidic environment in the stomach and high concentration of bile components in the intestine when animals consume feeds containing these organisms. These results therefore corroborate the previous results of Oloyede and Afolabi (2013) that isolated strains of Lactobacillus acidophilus and Lactobacillus plantarum with high probiotic characteristics from raw milk of WAD goats. In addition, many strains of these lactic acid bacteria have also been reported by many authors as probiotic bacteria and to a certain extent, are used in the production of probiotic preparations that are used in animals and human health (Bhattacharyya, 2009; Sarkono et al., 2010; Oloyede and Afolabi, 2013).

Bile resistance of some organisms has been reported to be related to specific enzyme activity, bile salt hydrolase (BSH), which helps to hydrolyse conjugated bile, thus reducing its toxic effect. The study therefore revealed that the potential probiotic lactic acid bacterial isolates which were able to survive high concentration of bile acid had high bile salt hydrolase (BSH) activity. BSH activity has mostly been found in organisms isolated from the intestines or faeces of animals, which is in accordance with the results of this study.

The taxonomy of lactic acid bacteria based on comparative $16 \mathrm{~S}$ ribosomal RNA sequencing analysis has revealed that some taxa generated on the basis of phenotypical features do not correspond with their phylogenetic relations. Molecular techniques are therefore important for the specific characterization of lactic acid bacterial strains. In this study, the 16S rRNA gene amplification using $27 \mathrm{~F}$ and $1492 \mathrm{R}$ primers revealed that the probiotic isolates were lactic acid bacteria and the lengths of amplification were $1,500 \mathrm{bp}$. These sizes were similar to the sizes previously obtained by many authors. Similarly, the polymerase chain reaction (PCR) results using butyrate kinase (buk) primer sets for detecting gene that codes for synthesis of butyrate confirmed that butyrate kinase gene was found in only one lactic acid bacterial isolate (Lactobacillus plantarum PLB5). Since the LAB used in this study were isolated from the faeces of WAD goats, the result of the present study is consistent with the previous reports that most gut microbes possess the genes for butyrate kinase (Barcenilla et al., 2000; Louis et al., 2004), but not in agreement with the report of Abbas (2009) who found gene for butyrate production (buk gene) in none of the LAB tested. However, other investigators had found butyrate kinase (buk) genes in isolates of Enterococcus faecalis (Louis et al., 2004) and Enterococcus durans with probiotic characteristics from human faeces (Raz et al., 2007). Although, studies have reported that lactobacilli and Bifidobacteria do not produce butyrate, the presence of butyrate kinase gene in Lactobacillus plantarum PLB5 revealed that very few strains of lactobacillus could be able to produce butyrate. This fatty acid provides energy to the animals for carrying out other metabolic activities in the body, enhancing the ruminal fermentation and the growth performance of the animals. Furthermore, butyrate provides a defence against cancer and ulcerative colitis in animals and humans, as well as used to promote the beneficial response of the immune system (Abbas, 2009). This acid also reduces the adhesion of harmful bacteria such as E. coli, Salmonella spp, Shigella spp and other pathogens on mucosal surfaces of the animals thereby affecting their colonization. It also lowers the $\mathrm{pH}$ of the GIT of the animals, thereby affecting the survival of the pathogens in the GIT of the animals and therefore, improving the health of the animals. Therefore, the use of Lactobacillus plantarum PLB5 observed in this study to possess butyrate kinase enzyme, as probiotics in livestock in Nigeria will not only improve their growth performance, but also improve their health.

In conclusion, the probiotic butyrate-producing Lactobacillus plantarum PLB5 isolated in this study could potentially make a significant contribution to the growth of livestock industry in Nigeria. However, in-vivo selection studies are needed to ascertain the colonization and adherence capacities of Lactobacillus plantarum PLB5 as well as its safety before the design of any animal intervention trials.

\section{Acknowledgement}

The authors acknowledge the supports of the Biotechnology Centre and Laboratory of Microbiology department, Federal University of Agriculture, Abeokuta, Nigeria for providing the enabling facilities for carrying out this research study. 


\section{References}

Abbas, K. A. (2009). The synergistic effects of probiotic microorganisms on the microbial production of butyrate in vitro. McNair Sch. Res. J. 2(1): 103- 114.

Abdul Hamid, T. H. T., Khan, A. J., Jalil, M. F. and Azhar, N. S. (2012). Isolation and screening of lactic acid bacteria, Lactococcus lactis from Clarias gariepinus (African catfish) with potential use as probiotic in aquaculture. Afr. J. Biotechnol. 11(29):7494-7499.

Adebayo, J. O. and Chineke, C. A. (2011). Evaluation of West African dwarf goat for some qualitative traits in Southwest Nigeria. Afr. J. Agric. Res. 6(28): 6204-6207.

Barcenilla, A., Pryde, S. E., Martin, J. C., Duncan, S. H., Stewart, C. S., Henderson, C. and Flint, H. J. (2000). Phylogenetic relationship of butyrateproducing bacteria from the human gut. Appl. Environ. Microbiol. 66: 1654-1661.

Bhattacharyya, B. K. (2009). Emergence of probiotics in therapeutic applications. International J. Pharm. Sci. Nanotech. 2(1): 383- 389.

Bujnakova, D., Strakova, E. and Kmet, V. (2013). In vitro evaluation of the safety and probiotic properties of Lactobacilli isolated from chicken and calves. Anaerobe. XXX: 1- 10.

Chen, H., Hopper, S. L., Li, X., Ljungdahl, L. G. and Cerniglia, C. E. (2006). Isolation of extremely ATrich genomic DNA and analysis of genes encoding carbohydrate- degrading enzymes from Orpinomyces sp. strain PC-2. Curr. Microbiol. 53: 396- 400.

Cross, M. L. (2002). Microbes versus microbes: immune signals generated by probiotic lactobacilli and their role in protection against microbial pathogens. FEMS Immun. Med. Microbiol. 34(4): 245-253.

DeFrain, J. M., Hippen, A. R., Kalscheur, K. F., and Schingoethe, D. J. (2004). Feeding lactose increases ruminal butyrate and plasma $\beta$ hydroxybutyrate in lactating dairy cows. J. Dairy Sci. 87: 2486-2494.

Hold, G. L., Schwiertz, A., Aminov, R. I, Blaut, M. and Flint, H. J. (2003). Oligonucleotide probes that detect quantitatively significant groups of butyrate- producing bacteria in human feces. Appl. Environ. Microbiol. 69: 4320-4324.

Holzapfel, W. H., Haberer, P., Geisen, R., Bjorkroth, J. and Schillinger, U. (2001). Taxonomy and important features of probiotic microorganisms in food and nutrition. Am. J. Clin. Nutr. 73: 365S- 373S.

Hoque, M. Z., Akter, F., Hossain, K. M., Rahman, M. S. M., Billah, M. M. and Islam, K. M. D. (2010). Isolation, identification and analysis of probiotic properties of Lactobacillus spp from selective regional yoghurts. World J. Dairy \& Food Sci. 5(1): 39- 46.

Jiang, H., Dong, H., Zhang, G., Yu, B., Chapman, L. R. and Fields, M.W. (2006). Microbial Diversity in Water and Sediment of Lake Chaka, an Athalassohaline Lake in Northwestern China. Appl. Environ. Microbiol. 72(6):3832-3845.

Louis, P., Duncan, S. H., McCrae, S. I., Millar, J., Jackson, M. S. and Flint, H. J. (2004). Restricted distribution of the butyrate kinase pathway among butyrate-producing bacteria from the human colon. J. Bacteriol. 186: 2099-2106.

Mercenier, A., Pavan, S. and Pot, B. (2003). Probiotics as biotherapeutic agents: present knowledge and future prospects. Curr. Pharm. Des. 9(2):175-191.

O'Hara, A. M., O'Regan, P., Fanning, A., O'Mahony, C. O., Macsharry, J., Lyons, A., Bienenstock, J., O'Mahony, L. and Shanahan, F. (2006). Functional modulation of human intestinal epithelial cell responses by Bifidobacterium infantis and Lactobacillus salivarius. Immunol. 118(2):202-215.

Oloyede, A. R. and Afolabi, O. R. (2013). Phenotypic characterization and in-vitro screening of Lactic acid bacteria from goat milk for probiotic use. J. Agric. Sci. Environ. 13(1): 50-59.

Oseni, S., Sonaiya, B., Omitogun, G., Ajayi, A. and Muritala, I. (2006). West African Dwarf Goat Production under Village Conditions: Characterisation and the Establishment of Breed Standards. Proc. Conference on International Agricultural Research for Development, Bonn, October 11-13.

Perea Velez, M., Hermans, K., Verhoeven, T.L.A., Lebeer, S.E., Vanderleyden, J. and De Keersmaecker, S.C.J. (2007). Identification and characterization of starter lactic acid bacteria and probiotics from Columbian dairy products. J. Appl. Microbiol. 103: 666-674. 
Raz, I., Gollop, N., Polak-Charcon, S. and Schwartz, B. (2007). Isolation and characterisation of new putative probiotic bacteria from human colonic flora. Brit. J. Nutr. 97: 725- 734.

Sarkono, M., Rahman, F. and Sofyan, Y. (2010). Isolation and identification of lactic acid bacteria from abalone (Haliotis asinina) as a potential candidate of probiotic. Biosci. 2(1): 38- 42.

Soccol, C. R., Vandenberghe, L. P., Spier, M. R., Medeiros, A. B. P., Yamaguishi, C. T., Lindner, J. D. D., Pandey, A. and Thomaz-Soccol, V. (2010). The potential of probiotics: A review. Food Technol. Biotechnol. 48(4): 413-434.

Sridhar, M., Kumar, D., Anandan, S., Prasad, C. S. and Sampath, K. T. (2010). Morphological and molecular characterization of polycentric rumen fungi belonging to the genus Orpinomyces isolated from Indian cattle and buffaloes. Res. J. Microbiol. 5: 581- 594. 